\title{
PENGARUH PROSES BELAJAR MENGAJAR DAN LINGKUNGAN DI KELAS TERHADAP PRESTASI BELAJAR MAHASISWA JURUSAN ADMINISTRASI NIAGA POLITEKNIK NEGERI MALANG
}

\author{
Masreviastuti \\ Jurusan Administrasi Niaga, Politeknik Negeri Malang \\ masreviastuti@polinema.ac.id
}

(Artikel diterima: November 2019, diterima untuk terbit: Desember 2019)

\begin{abstract}
Abstrak - Pendidikan adalah salah satu faktor yang sangat besar peranannya bagi kehidupan bangsa karena pendidikan dapat mendorong dan menentukan maju mundurnya proses pembangunan bangsa dalam segala bidang. Lingkungan belajar bagi mahasiswa diharapkan akan menimbulkan semangat untuk belajar dan akan menghasilkan prestasi yang baik yang pada akhirnya akan menjadi lulusan yang berkwalitas. Prsetasi belajar yang dicapai oleh seorang mahasiswa merupakan hasil interaksi antara berbagai faktor yang mempengaruhinya baik dari diri mahasiswa maupun dari luar mahasiswa. Penelitian ini bertujuan untuk mengetahui pengaruh proses belajar mengajar dan liungkungan belajar di kelas terhadap prestasi belajar mahasiswa. Agar memperoleh gambaran yang menyeluruh, maka obyek penelitiannya adalah seluruh mahasiswa tingkat satu D3 dan tingkat satu D4/pemasaran Jurusan administrasi Bisnis Politeknik Negeri Malang. Sehingga hasilnya diharapkan dapat dijadikan masukan terkait dengan proses belajar mengajar dan lingkungan belajar di kelas terhadap prestasi belajar pada mahasiswa.
\end{abstract}

Kata kunci: proses belajar mengajar, lingkungan belajar di kelas , prestasi belajar.

\section{Pendahuluan}

Proses belajar mengajar atau pembelajaran merupakan suatu kegiatan melaksanakan kurikulum dalam lembaga pendidikan supaya mahasiswa dapat mencapai tujuan yang telah ditetapkan. Tujuan pendidikan pada dasarnya mengantarkan mahasiswa menuju perubahan tingkah laku baik intelektual, moral, maupun Sosial budaya. Dengan pendidikan diharapkan supaya mahasiswa dapat hidup mandiri sebagai individu maupun makhluk social.

Sesuai dengan uraian latar belakang masalah, maka pokok permasalahannya yang ada dapat dirumuskan sebagai berikut: pengaruh secara parsial antara proses belajar mengajar terhadap prestas belajar, pengaruh secara parsial antara lingkungan belajar di kelas terhadap prestasi, dan pengaruh secara simultan antara proses belajar mengajar dan lingkungan belajar di kelas terhadap prestasi belajar.

Penelitian ini dilakukan terhadap Mahasiswa Polinema Jurusan Administrasi Niaga semester 1 (satu) D4 Pemasaran (hanya 3 kelas) tahun ajaran 2018/2019.

Hasil penelitian tentang "Pengaruh Proses Belajar Mengajar dan Lingkungan Belajar di Kelas Terhadap Prestasi Belajar Mahasiswa Jurusan Administrasi Niaga Politeknik Negeri Malang" diharapkan dapat memberi implikasi: Akademis, dapat dipakai sebagai masukan dalam menambah bahan ajar mata kuliah MSDM dan sebagai bahan referensi dalam mengadakan penelitian di bidang pengembangan SDM.

\section{Tinjauan Pustaka}

Belajar pada hakekatnya merupakan kegiatan yang dilakukan secara sadar untuk menghasilkan suatu perubahan, menyangkut pengetahuan, keterampilan, sikap, dan nilai-nilai (Hamzah, 2009).

Menurut wahyuningsih dan Djazari (2013), lingkungan belajar merupakan lingkungan yang berpengaruh terhadap proses belajar baik lingkungan fisik maupun lingkungan sosial.

Besar Bahasa Indonesia (2005) berarti:

1. Penguasaan pengetahuan atau keterampilan yang dikembangkan oleh mata pelajaran, lazimnya ditunjukkan dengan nilai tes atau angka nilai yang diberikan guru.

2. Kemampuan yang sungguh-sungguh ada atau dapat diamati dan yang dapat diukur langsung dengan tes tertentu.

Belajar pada hakekatnya merupakan kegiatan yang dilakukan secara sadar untuk menghasilkan suatu perubahan, menyangkut pengetahuan, keterampilan, sikap, dan nilai-nilai (Hamzah, 2009). Dapat disimpulkan Semakin bagus penguasaan mahasiswa terhadap pembelajaran semakin baik pula prestsi belajar yang didapatkan .

Melalui lingkungan belajar, seseorang bisa mendapatkan pendidikan baik secara langsung maupun tidak langsung yang dipengaruhi oleh lingkungan alami maupun lingkungan sosial. Menurut Baharudin, (2007) dalam ningrum (2013), lingkungan belajar merupakan faktor eksternal yang dapat mempengaruhi perkembangan dan memberikan pengaruh bagi siswa dalam proses belajarnya.

Proses belajar mengajar merupakan proses yang sistematik, artinya proses yang dilakukan oleh pengajar dan siswa di tempat belajar dengan melibatkan sub-sub bagian, komponen-komponen atau unsur-unsur yang saling berinteraksi untuk mencapai suatu tujuan.

Lingkungan belajar seperti sarana dan prasarana, luas lingkungan, penerangan dan kebisingan memiliki pengaruh yang besar terhadap penilaian menyenangkan atau tidaknya lingkungan belajar sehingga dapat mempengaruhi motivasi dan proses pembelajaran.

Prestasi dapat pula didefinisikan sebagai berikut:" Nilai merupakan perumusan terakhir yang dapat diberikan oleh guru mengenai kemajuan atau prestasi belajar siswa selama masa tertentu". Jadi prestasi adalah hasil usaha siswa selama masa tertentu melakukan kegiatan.

Untuk lebih jelasnya kerangka konseptual tersebut 
dapat digambarkan dalam suatu model konsep pada gambar 2.1

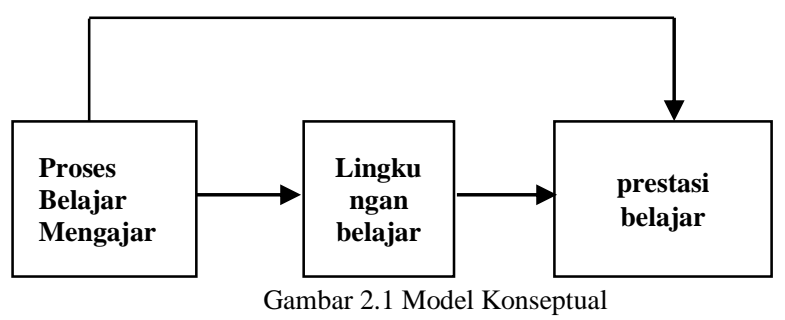

III. METODE

\subsection{Hipotesis}

Berdasarkan kajian pustaka dan tinjauan teoritis disusun rumusan hipotesis berikut:

H1 : Diduga ada pengaruh yang signifikan antara variabel proses belajar mengajar terhadap variabel prestasi belajar

H2 : Diduga ada pengaruh yang signifikan antara variabel lingkungan belajar terhadap variabel prestasi belajar

H3 : Diduga ada pengaruh yang signifikan antara variabel proses belajar mengajar dan lingkungan belajar terhadap variabel prestasi belajar.

\subsection{Jenis Penelitian}

Penelitian merupakan cara ilmiah untuk mendapatkan data dengan tujuan dan kegunaan tertentu (Sugiyono,2012). Berdasarkan tujuan penelitian yang hendak dicapai, jenis penelitian yang digunakan adalah penelitian penjelasan (explanatory research), yaitu penelitian yang mengkaji hubungan antara variabel-variabel penelitian dan menguji hipotesis yang telah dirumuskan sebelumnya. Jenis penelitian ini dipilih karena sesuai dengan tujuan penelitian, yaitu untuk menjelaskan hubungan kausal yang terjadi antara variabel-variabel yang diteliti dengan melakukan pengujian hipotesis.

\subsection{Tempat Penelitian} Malang.

Penelitian ini dilaksanakan di Politeknik Negeri

\subsection{Populasi dan Sampel Populasi}

Populasi dalam penelitian ini adalah mahasiswa semester 1 D4/Pemasaran Politeknik Negeri Malang, yaitu berjumlah 90 .

\subsection{Sampel dan Teknik Sampling}

Untuk menetapkan jumlah sampel dalam penelitian itu dihitung dengan menggunakan rumus Slovin.

Berdasarkan jumlah populasi sebesar 90 dan tingkat posisi sebesar $10 \%$ maka jumlah sampel dalam penelitian ini adalah sebagai berikut:

Dari hasil perhitungan diatas, maka dalam penelitian ini sampel yang digunakan adalah berjumlah mahasiswa 90

\subsection{Skala Pengukuran}

Berhubung penelitian ini menggunakan hipotesis, maka untuk keperluan uji hipotes isi ini diperlukan skala pengukuran pada variabel yang telah ditetapkan.Skala pengukuran yang digunakan adalah Skala Likert dengan skala 5 .

\subsection{Teknik Pengumpulan Data \\ - Kuesioner \\ - Wawancara \\ - Observasi}

\subsection{Variabel Penelitian}

Mendasarkan pada model hipotesis yang tersaji pada Gambar 2.2, maka variabel yang digunakan seperti yang tersaji pada Tabel 1.1 berikut:

Tabel 1.1. Pengelompokkan Variabel Penelitian

\begin{tabular}{|l|c|c|}
\hline \multirow{2}{*}{ No. } & \multicolumn{2}{|c|}{ Variabel } \\
\cline { 2 - 3 } & Eksogen & Endogen \\
\hline 1 & $\begin{array}{c}\text { Proses belajar mengajar } \\
(\mathrm{X} 1)\end{array}$ & Prestasi Belajar (Y) \\
\hline 2 & $\begin{array}{c}\text { Lingkungan Belajar di } \\
\text { Kelas (X2) }\end{array}$ & \\
\hline
\end{tabular}

\subsection{Uji Validitas}

Menurut Sugiyono (2012) validitas merupakan hasil penelitian dimana terdapat kesamaan antara data yang terkumpul dengan data yang sesungguhnya terjadi pada obyek yang diteliti. Valid berarti instrumen tersebut dapat digunakan untuk mengukur apa yang hendak diukur. Pengujian validitas dalam penelitian ini mempergunakan analisis korelasi product moment, dengan mengkorelasikan skor setiap item dengan skor total sebagai jumlah skor item.. Adapun formulasi korelasi product moment (Sugiyono, 2012) adalah sebagai berikut:

$$
\mathrm{r}=\frac{\mathrm{n} \Sigma \mathrm{XY}-\Sigma \mathrm{X} \Sigma \mathrm{Y}}{\sqrt{\left(\mathrm{n} \Sigma \mathrm{X}^{2}-\left(\sum \mathrm{X}\right)^{2}\right)\left(\mathrm{n} \Sigma \mathrm{Y}^{2}-\left(\sum Y\right)^{2}\right)}}
$$

Keterangan :

$\mathrm{r}=$ Koefisien korelasi

$\mathrm{X}=$ Skor butir pertanyaan

$\mathrm{Y}=$ Total skor variabel

$\mathrm{n}=$ Jumlah responden

Pengujian dilakukan pada taraf $\alpha=0,05$ dengan kriteria pengujian:

Jika probabilitas $<0,05$ atau nilai $r_{\text {hitung }}>r_{\text {tabel }}$ maka butir pertanyaan valid

Jika probabilitas $>0,05$ atau nilai $r_{\text {hitung }}<r_{\text {tabel }}$ maka butir pertanyaan tidak valid

\subsection{Uji Validitas}

Menurut Sugiyono (2001:267) validitas merupakan hasil penelitian dimana terdapat kesamaan antara data yang terkumpul dengan data yang sesungguhnya terjadi pada obyek yang diteliti. Valid berarti instrumen tersebut dapat digunakan untuk mengukur apa yang hendak diukur. Pengujian validitas dalam penelitian ini mempergunakan analisis korelasi product moment, dengan mengkorelasikan skor setiap item dengan skor total sebagai jumlah skor item.. Adapun formulasi korelasi product moment (Sugiyono, 2001 : 250) adalah sebagai berikut: 


$$
\mathrm{r}=\frac{\mathrm{n} \Sigma \mathrm{XY}-\Sigma \mathrm{X} \Sigma \mathrm{Y}}{\sqrt{\left(\mathrm{n} \Sigma \mathrm{X}^{2}-(\Sigma \mathrm{X})^{2}\right)\left(\mathrm{n} \Sigma \mathrm{Y}^{2}-(\Sigma \mathrm{Y})^{2}\right)}}
$$

Keterangan :

$\mathrm{r}=$ Koefisien korelasi

$\mathrm{X}=$ Skor butir pertanyaan

$\mathrm{Y}=$ Total skor variabel

$\mathrm{n}=$ Jumlah responden

Pengujian dilakukan pada taraf $\alpha=0,05$ dengan kriteria pengujian:

Jika probabilitas $<0,05$ atau nilai $r_{\text {hitung }}>r_{\text {tabel }}$ maka butir pertanyaan valid

Jika probabilitas $>0,05$ atau nilai $r_{\text {hitung }}<r_{\text {tabel }}$ maka butir pertanyaan tidak valid

\subsection{Reliabilitas}

Suatu instrumen dikatakan reliabel jika instrumen tersebut apabila digunakan beberapa kali untuk mengukur obyek yang sama akan menghasilkan hasil yang sama (Sugiyono, 2001: 97). Uji reliabilitas dilakukan dengan menggunakan formula Alpha Cornbach (Nurgiyantoro, 2000:310) dengan rumus sebagai berikut

$\mathrm{r}=\frac{k}{k-1}\left[1-\frac{\Sigma \sigma^{2}}{\sigma^{2}}\right]$

Keterangan :

$\mathrm{r} \quad=$ Koefisien reliabilitas

$\mathrm{k}=$ Jumah butir pertanyaan

$\sigma \mathrm{i}^{2}=$ varian butir pertanyaan

$\sigma^{2}=$ varian skor tes

Instrumen dikatakan reliabilitas bilamana koefisien reliabilitasnya mencapai 0,60 (Nurgiyantoro, 2000:312). Adapun perhitungan untuk pengujian reliabilitas dilaksanakan dengan bantuan program komputer SPSS 16.

\section{Analisis Data}

\subsection{Analisis Statistik Deskriptif}

Analisis ini digunakan untuk memberikan gambaran mengenai hasil tabulasi data kuesioner yang telah diisi responden. Gambaran ringkas pengolahan data nominal dengan menggunakan data deskriptif meliputi : karakteristik responden yang dinyatakan dalam angka dan prosentase serta tabulasi frekwensi item pernyataan kuesioner yang juga dinyatakan dalam angka dan prosentase.

Teknik analisis regresi linier berganda ini dipergunakan untuk mengetahui pengaruh variabel bebas terhadap variabel terikat (Umar, 2001:188). Adapun model regresni linier berganda dalam penelitian ini adalah sebagai berikut

$\mathrm{Y}=\mathrm{a}+\mathrm{b}_{1} \mathrm{X}_{1}+\mathrm{b}_{2} \mathrm{X}_{2}+\mathrm{e}$

dimana :

$\mathrm{Y}=$ PrestasiAkademik

$\mathrm{a}=$ Konstanta

$\mathrm{b}_{1}=$ Koefisien regresi variabel gayakepemimpinan

$\mathrm{b}_{2}=$ Koefisien regresi variabel motivasidiri

$\mathrm{X}_{1}=$ Variabel Gaya kepemimpinan

$\mathrm{X}_{2}=$ Variabel Motivasidiri

$\mathrm{e}=$ Variabel pengganggu (error)

\subsection{Uji Hipotesis I (Uji Simultan)}

Uji hipotesis I dilakukan dengan menggunakan Uji $F$ yaitu menguji signifikansi pengaruh variabel bebas secara simultan terhadap variabel terikat. Pengujiannya dilakukan dengan membandingkan besarnya nilai $F_{\text {hitung }}$ dengan besarnya nilai $F_{\text {tabel }}$, dimana bila besarnya nilai $F_{\text {hitung }}$ lebih besar dari nilai $F_{\text {tabel}}$, berarti bahwa secara serentak (bersama-sama) variabel bebas mempengaruhi variabel tidak bebas, dan sebaliknya, jika $\mathrm{F}_{\text {hitung }}$ lebih kecil daripada nilai $\mathrm{F}_{\text {tabel}}$, berarti nilai variabel bergantung atau variabel tidak bebas tidak dipengaruhi oleh variabel bebasnya.

\subsection{Deskripsi Karateristik Responden}

Berdasarakan hasil penelitian yang dilakukan terhadap 90 responden yang Kuliah di Poltek Kota Malang melalui penyebaran kuisoner maka, diperoleh data berdasarkan usia, jenis kelamin, pakerjaan, dan frekuensi berkunjung. Dapat dilihat pada tabel berikut:

Tabel 4.1. Deskripsi Karateristik Responden Berdasarkan Usia

\begin{tabular}{|c|c|c|}
\hline $\begin{array}{c}\text { Usia } \\
\text { (Tahun) }\end{array}$ & Frekuensi & $\begin{array}{c}\text { Presentase } \\
(\%)\end{array}$ \\
\hline$<20$ tahun & 22 & $24.44 \%$ \\
\hline $\begin{array}{c}18-20 \\
\text { tahun }\end{array}$ & 59 & $65.56 \%$ \\
\hline$>20$ tahun & 9 & $10.00 \%$ \\
\hline Total & 90 & $100 \%$ \\
\hline
\end{tabular}

Dari hasil survei yang dilakukan terhadap 90 orang responden menunjukan usia responden dikisaran antara di bawah 21 tahun sampai 251 tahun. Frekuensi paling banyak di usia 18-19 tahun dengan jumlah respondenya 59 orang $(65,56 \%), 22$ orang $(24,44 \%)$ berusia $<20$ tahun, dan 9 orang $(10 \%)$ diusia $>20$ tahun.

Tabel 4.2 Deskripsi Karateristik Responden berdasarkan jenis kelamin

\begin{tabular}{|c|c|c|}
\hline $\begin{array}{c}\text { Jenis } \\
\text { kelamin }\end{array}$ & Frekuensi & $\begin{array}{c}\text { Presentase } \\
(\boldsymbol{\%})\end{array}$ \\
\hline Laki-laki & 39 & $43.33 \%$ \\
\hline Perempuan & 51 & $56.67 \%$ \\
\hline Total & 90 & $100 \%$ \\
\hline
\end{tabular}

Dari hasil survei yang dilakukan terhadap 90 orang responden menunjukan jumlah responden sebanyak 39 orang $(43,33 \%)$ berjenis kelamin perempuan dan 51 orang $(56,67 \%)$ berjenis kelamin laki-laki.

\subsection{Uji Validitas dan Reliabilitas}

Tingkat validitas diperoleh dengan membandingkan nilai $r$ hitung denganprobabilitas. Bila probabilitas $\geq 0,03$ (3\%), maka item-item dalam setiap variabel tersebut dinyatakan valid dan jika sebaliknya maka dinyatakan tidak valid.

Hasil uji validitas yang disajikan pada tabel 4.3 menunjukkan masing-masing butir pertanyaan mempunyai 
nilai koefisien korelasi > 0,3 dengan nilai signifikansi < 0,05. Maka kesimpulannya semua item-item dalam penelitian ini dikatakan valid.

Suatu varian reliabel jika memiliki nilai Cronbach's Alpha $\geq 0,60$. Setelah dilakukan pengujian terhadap adata maka dapat diketahui bahwa data yang diperoleh adalah valid dan reliable sehingga proses analisis berikutnya dapat dilanjutkan.

Instrumen dinyatakan reliabel jika nilai Alpha Cronbach paling tidak mencapai 0,6. Berdasarkan hasil uji reliabilitas pada tabel 4.7 dapat diketahui bahwa nilai reliabilitas yang dicapai pada masing-masing variabel lebih besar dari 0,6 artinya instrumen yang digunakan reliabel.

\subsection{Deskripsi Variabel Penelitian}

Sebagai acuan untuk menentukan panjang pendeknya interval yang ada dalam penelitian ini, penulis juga mencantumkan tabel 4.5 yang digunakan untuk alat ukur sebagai analisis deskripsi jawaban responden.

Berdasarkan rentang skor diatas, maka interval $=($ skor tertinggi-skor terendah)/jumlah kelas $=(5-1) / 5=0,8$. Sehingga dapat ditentukan interval masing-masing kelas adalah sebagai berikut:

$$
\begin{array}{ll}
\text { 1. } & 1,00-1,80=\text { sangat rendah/sangat kecil/ sangat } \\
\text { 2. } & 1,81-2,60=\text { rendah/kecil/lemah } \\
\text { 3. } & 2,61-3,40=\text { cukup } \\
\text { 4. } & 3,41-4,20=\text { tinggi/besar/kuat/naik } \\
\text { 5. } & 4,21-5,00=\text { sangat tinggi/ sangat besar/ sangat } \\
& \text { kuat }
\end{array}
$$

Keterangan :

$\mathrm{X}_{1.1}=$ Dosen memberikan materi sampai mahasiswa benar benar mengerti

$\mathrm{X}_{1.2}=$ Dosen memberikan materi dengan harapan mahasiswa bisa meraih nilai sangat memuaskan

$\mathrm{X}_{1.3}=$ Dosen selalu memberikan pengarahan pada mahasiswa

$\mathrm{X}_{1.4}=$ Dosen selalu memberikan motivasi pada mahasiswa

$\mathrm{X}_{1.5}=$ Dosen memberikan materi dengan menggunakan konsep

$\mathrm{X}_{1.6}=$ Dosen memberikan materi dengan memanfaatkan LCD

$\mathrm{X}_{1.7}=$ Dosen memberikan materi sesuai gaya mengajar masing masing

$\mathrm{X}_{1.8}=$ Dosen setiap tatap muka selalu berinteraksi dengan mahasiswa

Pada item dosen memberikan materi sampai mahasiswa benar benar mengerti $\left(\mathrm{X}_{1.1}\right)$ menunjukkan bahwa dari 90 responden, sebanyak 1 responden $(1.1 \%)$ menyatakan tidak setuju, sebanyak 8 responden $(8.9 \%)$ menyatakan cukup setuju, sebanyak 47 responden $(52.2 \%)$ menyatakan setuju, dan sebanyak 34 Responden (37.8\%) menyatakan sangat setuju.Pada item dosen memberikan materi dengan harapan mahasiswa bisa meraih nilai sangat memuaskan $\left(\mathrm{X}_{1.2}\right)$ menunjukkan bahwa dari 90 responden, sebanyak 6 responden $(6.7 \%)$ menyatakan cukup setuju, sebanyak 28 responden $(31.1 \%)$ menyatakan setuju, sebanyak 56 responden $(62.2 \%)$ menyatakan sangat setuju. Pada item dosen selalu memberikan pengarahan pada mahasiswa $\left(\mathrm{X}_{1.3}\right)$ menunjukkan bahwa dari 90 responden, sebanyak 11 responden (12.2\%) menyatakan cukup setuju, sebanyak 23 responden $(25.6 \%)$ menyatakan setuju, sebanyak 56 responden $(62.2 \%)$ menyatakan sangat setuju. Pada item dosen selalu memberikan motivasi pada mahasiswa $\left(\mathrm{X}_{1.4}\right)$ menunjukkan bahwa dari 90 responden, sebanyak 5 responden $(5.6 \%)$ menyatakan cukup setuju, sebanyak 23 responden $(25.6 \%)$ menyatakan setuju, sebanyak 62 responden $(68.9 \%)$ menyatakan sangat setuju.Pada item dosen memberikan materi dengan menggunakan konsep $\left(\mathrm{X}_{1.5}\right)$ menunjukkan bahwa dari 90 responden, sebanyak 3 responden $(3.3 \%)$ menyatakan cukup setuju, sebanyak41 responden $(45.6 \%)$ menyatakan setuju, sebanyak 59 responden $(65.6 \%)$ menyatakan sangat setuju. Pada item dosen memberikan materi dengan memanfaatkan $\operatorname{LCD}\left(\mathrm{X}_{1.6}\right)$ menunjukkan bahwa dari 90 responden, sebanyak3 responden $(3.3 \%)$ menyatakan cukup setuju, sebanyak 41 responden $(45.6 \%)$ menyatakan setuju, dan sebanyak46 responden $(51.1 \%)$ menyatakan sangat setuju. Pada item dosen memberikan materi sesuai gaya mengajar masing $\operatorname{masing}\left(\mathrm{X}_{1.7}\right)$ menunjukkan bahwa dari 100 responden, sebanyak 3 responden (3.3\%) menyatakan cukup setuju, sebanyak 25 responden $(27.8 \%)$ menyatakan setuju, sebanyak 62 responden $(68.9 \%)$ menyatakan sangat setuju. Pada item dosen setiap tatap muka selalu berinteraksi dengan mahasiswa $\left(X_{1.8}\right)$ menunjukkan bahwa dari 90 responden, sebanyak 4 responden $(4.4 \%)$ menyatakan cukup setuju, sebanyak 24responden $(26.7 \%)$ menyatakan setuju, dan sebanyak 62 responden $(68.9 \%)$ menyatakan sangat setuju.

\subsection{Lingkungan Belajar di Kelas $\left(X_{2}\right)$ \\ Keterangan:}

$\mathrm{X}_{2.1}=$ Apakah ruang tempat belajar sudah sesuai

$\mathrm{X}_{2.2}=$ Apakah suasana dalam rumah sepi belajar

$\mathrm{X}_{2.3}=$ Apakah gedung kampus mendukung untuk akrab

$\mathrm{X}_{2.4}=$ Apakah hubungan mahasiswa dan dosen sangat

$\mathrm{X}_{2.5}=$ Apakah kegiatan mahasiswa dengan masyarakat ada kaitannya

$\mathrm{X}_{2.6}=$ Apakah media massa sering digunakan mahasiswa.

Pada item apakah ruang tempat belajar sudah sesuai $\left(\mathrm{X}_{2.1}\right)$ menunjukkan bahwa dari 90 responden, sebanyak 3 responden $(3.3 \%)$ menyatakan cukup setuju, sebanyak 49 responden $(54.4 \%)$ menyatakan setuju, sebanyak 38 responden (42.2\%) menyatakan sangat setuju. Pada itemapakah suasana dalam rumah $\operatorname{sepi}\left(\mathrm{X}_{2.2}\right)$ menunjukkan bahwa dari 90 responden, sebanyak 14 responden $(15.6 \%)$ menyatakan cukup setuju, sebanyak 54 responden $(60.0 \%)$ menyatakan setuju, sebanyak 22 responden $(24.4 \%)$ menyatakan sangat setuju. Pada item apakah gedung kampus mendukung untuk belajar $\left(\mathrm{X}_{2.3}\right)$ menunjukkan bahwa dari 90 responden, sebanyak 6 responden $(6.7 \%)$ menyatakan cukup setuju, sebanyak 26 responden $(28.9 \%)$ menyatakan setuju, sebanyak 58 responden $(64.4 \%)$ menyatakan sangat setuju. Pada item apakah hubungan mahasiswa dan dosen sangat $\operatorname{akrab}\left(\mathrm{X}_{2.4}\right)$ menunjukkan bahwa dari 90 responden, sebanyak3 responden $(3.3 \%)$ menyatakan tidak setuju, sebanyak 19 responden $(21.1 \%)$ menyatakan cukup setuju, sebanyak 38 responden $(42.2 \%)$ menyatakan setuju, dan sebanyak30 responden $(33.3 \%)$ menyatakan sangat setuju.Pada item apakah kegiatan mahasiswa dengan masyarakat ada kaitannya $\left(\mathrm{X}_{2.5}\right)$ menunjukkan bahwa dari 90 responden, sebanyak 2 responden $(2.2 \%)$ menyatakantidak setuju, sebanyak12 responden (13.3\%) menyatakan cukup setuju, 
sebanyak 40 responden $(44.4 \%)$ menyatakan setuju, sebanyak 36responden $(30.0 \%)$ menyatakan sangat setuju. Pada itemapakah media massa sering digunakan mahasiswa $\left(\mathrm{X}_{2.6}\right)$ menunjukkan bahwa dari 90 responden, sebanyak 3responden $(3.3 \%)$ menyatakantidak setuju, sebanyak 9 responden $(10.0 \%)$ menyatakan cukup setuju,sebanyak 44 responden $(48.9 \%)$ menyatakan setuju sebanyak 34 responden $(37.8 \%)$ menyatakan sangat setuju.

\subsection{Prestasi Belajar $(Y)$}

Pada item mahasiswa dapat menunjukkan nilai yang lebih baik $\left(\mathrm{Y}_{1}\right)$ menunjukkan bahwa dari 90 responden, sebanyak 2 responden $(2.2 \%)$ menyatakan sangat tidak setuju, sebanyak 15 responden $(16.7 \%)$ menyatakan tidak setuju,sebanyak 2 responden $(2.2 \%)$ menyatakan cukup setuju, sebanyak 24 responden $(26.7 \%)$ menyatakan setuju,sebanyak 47responden (52.2\%)menyatakan sangat setuju. Pada item mahasiswa dapat membandingkan prestasi dirinya dengan teman yang lain $\left(\mathrm{Y}_{2}\right)$ menunjukkan bahwa dari 90 responden, sebanyak 4 responden (4.4\%) menyatakan sangat tidak setuju, sebanyak 13 responden (14.4\%) menyatakan tidak setuju, sebanyak 1 responden $(1.1 \%)$ menyatakan cukup setuju, sebanyak 23 responden (25.6\%) menyatakan setuju dan sebanyak 49 responden (54.4\%) menyatakan sangat setuju. Pada item mahasiswa dapat menjelaskan materi yang telah dijelaskan oleh dosen $\left(\mathrm{Y}_{3}\right)$ menunjukkan bahwa dari 100 responden, sebanyak 4 responden $(4.4 \%)$ menyatakan sangat tidak setuju, sebanyak11 responden (12.2\%) menyatakan tidak setuju, sebanyak 9 responden $(10.0 \%)$ menyatakan cukup setuju,sebanyak 22 responden $(24.4 \%)$ menyatakan setuju dan sebanyak44 responden (48.9\%) menyatakan sangat setuju. Pada item mahasiswa dapat menjelaskan materi yang telah dijelaskan oleh dosen. $\left(\mathrm{Y}_{4}\right)$ menunjukkan bahwa dari 90 responden, sebanyak 4responden $(4.4 \%)$ menyatakan sangat tidak setuju, sebanyak 12 responden (13.3\%) menyatakan tidak setuju, sebanyak 13 responden $(14.4 \%)$ menyatakan cukup setuju, sebanyak 16 responden $(17.8 \%)$ menyatakan setuju dan sebanyak 45responden (50.0\%) menyatakan sangat setuju. Pada item mahasiswa dapat memberikan contoh materi yang diberikan dosen $\left(\mathrm{Y}_{5}\right)$ menunjukkan bahwa dari 90 responden, sebanyak 5 responden $(5.6 \%)$ menyatakansangat tidak setuju, sebanyak 12 responden $(13.3 \%)$ menyatakantidak setuju,sebanyak 15 responden $(16.7 \%)$ menyatakan cukup setuju,sebanyak 32 responden (35.6\%) menyatakan setuju sebanyak 26 responden $(28.9 \%)$ menyatakan sangat setuju.

Pada item mahasiswa dapat menggunakan secara tepat antar teori dan contoh soal $\left(\mathrm{Y}_{6}\right)$ menunjukkan bahwa dari 90 responden,sebanyak 2 responden $(2.2 \%)$ menyatakan sangat tidak setuju sebanyak sebanyak 15 responden (16.7\%) menyatakan tidak setuju sebanyak 9responden (10.0\%) menyatakan cukup setuju, sebanyak 34 responden $(37.8 \%)$ menyatakan setuju, sebanyak 30 responden (33.3\%) menyatakan sangat setuju. Pada item mahasiswa dapat menyebutkan pertanyaan yang diberikan $\operatorname{dosen}\left(\mathrm{Y}_{7}\right)$ menunjukkan bahwa dari 90 responden,sebanyak 2 responden $(2.2 \%)$ menyatakan sangat tidak setuju, sebanyak 15 responden $(16.7 \%)$ menyatakan tidak setuju, sebanyak 7 responden $(7.8 \%)$ menyatakan cukup setuju, sebanyak 26 responden $(28.9 \%)$ menyatakan setuju, dan sebanyak 40 responden $(44.4 \%)$ menyatakan sangat setuju. Pada item mahasiswa dapat menunjukkan atas prestasinya $\left(\mathrm{Y}_{8}\right)$ menunjukkan bahwa dari 90 responden, sebanyak 1 responden $(1.1 \%)$ menyatakan sangat tidak setuju, sebanyak 16 responden (17.8\%) menyatakan tidak setuju, sebanyak 4 responden $(4.4 \%)$ menyatakan cukup setuju, sebanyak 21 responden $(23.3 \%)$ menyatakan setuju, sebanyak 48 responden $(53.3 \%)$ menyatakan sangat setuju.

\subsection{Analisis Statistik Inferensial}

Dilakukan untuk menguji data variabel bebas $(\mathrm{X})$ dan data variable terikat $(\mathrm{Y})$ pada persamaan regresi yang dihasilkan yang berdistribusi normal atau berdistribusi tidak normal. Persamaan dikatakan baik jika mempunyai data variabel bebas dan data terkait berdistribusi mendekati normal atau normal sama sekai dan uji dilakukan dengan uji stati:

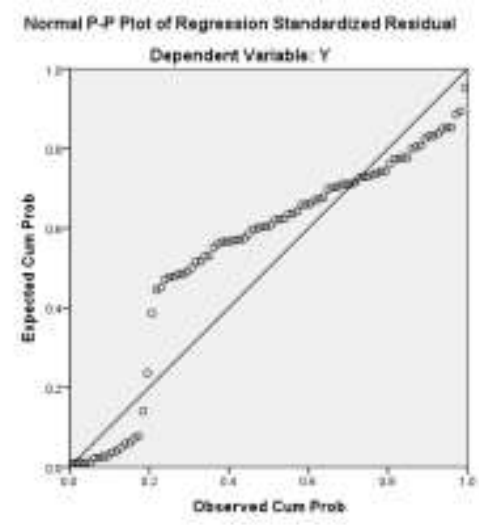

Gambar 4.1 Hasil Uji Normalitas

Sumber: Data primer diolah, 2019

Berdasarkan Gambar 4.1 di atas diketahui bahwa data berdistribusi normal, dimana data mendekati garis diagonal.

Pada pengujian autokorelasi digunakan uji DurbinWatson untuk mengetahui ada tidaknya autokorelasi pada model regresi dan berikut nilai Durbin-Watson yang diperoleh melalui hasil estimasi model regresi.Cara untuk mendeteksi ada tidaknya autokorelasi dalam penelitian ini adalah dengan menggunakan perhitungan nilai statistik Durbin-Watson (D-W). Menurut Jonathan Sarwono (2012:28) terjadi autokorelasi jika durbin watson sebesar $<1$ dan $>3$.

Tabel 4.3. Tabel autokorelasi

\begin{tabular}{|l|r|r|}
\hline \multirow{2}{*}{ Variabel Bebas } & \multicolumn{2}{|c|}{ Collinearity Statistics } \\
\cline { 2 - 3 } & Tolerance & \multicolumn{1}{c|}{ VIF } \\
\hline $\begin{array}{l}\text { Proses Belajar } \\
\text { Mengajar(X1) }\end{array}$ & 0.462 & 2.166 \\
\hline $\begin{array}{l}\text { Lingkungan Belajar } \\
(\mathrm{X} 2)\end{array}$ & 0.462 & 2.166 \\
\hline
\end{tabular}

Berdasarkan tabel 4.3. diatas diketahui nilai Durbin Wotsen sebesar 1.038 hal ini menunjukan bahwa data tidak terkena autokorelasi. Karena data D-W berada pada nilai $<1$ dan $>3$.

Uji asumsi tentang multikolinieritas ini dimaksudkan untuk membuktikan atau menguji ada tidaknya hubungan yang linier antara variabel bebas. Pada asumsi ini diharapkan dapat dilakukan dengan melihat dari Variance Inflation Factor (VIF) dan nilai tolerance dari masingmasing variabel bebas terhadap variabel terikatnya. Jika nilai VIF tidak lebih dari 10 dan nilai tolerance $>0,1$ maka model dinyatakan tidak terdapat gejala multikolinieritas nilai VIF dan tolerance. Hasil pengujian asumsi 
multikolinieritas dapat dilihat pada tabel 4.4.

Uji heterokedastisitas digunakan untuk mengetahui apakah residual memiliki ragam yang homogen (konstan) atau tidak.Pengujian heterokedastisitas diharapkan residual memiliki ragam yang homogen. Pengujian heterokedastisitas dapat dilihat melalui scatter plot. Residual dikatakan memiliki ragam yang homogen apabila titik-titik residual pada scatter plot menyebar secara acak.

Dari hasil pengujian pada gambar 4.2 di dapat bahwa diagram tampilannya scatter plot tidak membentuk pola tertentu. Hal ini dapat disimpulkan bahwa tidak terdapat gejala heterokedastisitas.Hasil pengujian asumsi heterokedastisitas dapat dilihat pada gambar 4.2.

Tabel 4.4. Hasil uji heterokedastisitas

\begin{tabular}{|c|c|c|c|c|}
\hline Model & $\mathbf{R}$ & $\begin{array}{c}\mathbf{R} \\
\text { Square }\end{array}$ & $\begin{array}{c}\text { Adjusted R } \\
\text { Square }\end{array}$ & $\begin{array}{c}\text { Std. Error } \\
\text { of the } \\
\text { Estimate }\end{array}$ \\
\hline 1 & $0,527^{\mathrm{a}}$ & 0,277 & 0,261 & 7.754 \\
\hline
\end{tabular}

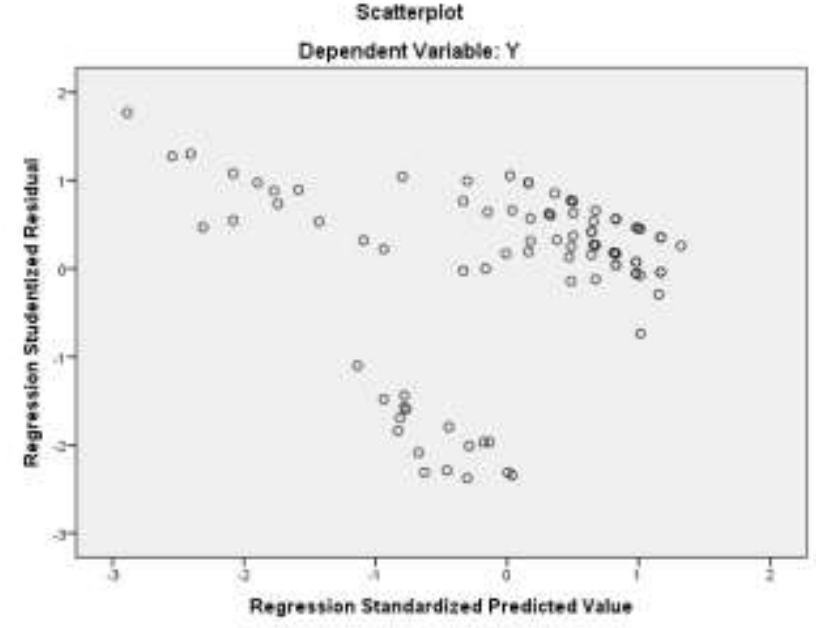

Gambar 4.2 Hasil Uji Heterokedastisitas

\subsection{Analisis Regresi Linier Berganda}

Analisis regresi ini digunakan untuk menghitung besarnya pengaruh antara variabel bebas yaitu Proses Belajar Mengajar, Lingkungan Belajar, terhadap variabel terikat yaitu Prestasi Belajar.Persamaan regresi digunakan untuk mengetahui bentuk hubungan antara variabel bebas dengan variabel terikat dengan menggunakan bantuan SPSS 23 for windows.

Berdasarkan hasil perhitungan dari analisis regresi linier berganda, maka dapat disimpulkan persamaan regresinya yaitu:

$$
\mathrm{Y}=15.613+0.736 \mathrm{X}_{1}+0,808 \mathrm{X}_{2}+8.450
$$

Dari persamaan regresi linier berganda tersebut dapat diketahui bahwa:

$\mathrm{X}_{1} \quad=$ Proses Belajar Mengajar

$\mathrm{X}_{2} \quad=$ Lingkungan Belajar

a. Konstanta sebesar 15.613 menunjukkan bahwa variabel Proses Belajar Mengajar(X1), Lingkungan Belajar(X2), diasumsikan 0, maka besarnya variabel terhadap variabel Prestasi Belajar(Y)adalah 15.613.

b. Koefisien regresi variabel Proses Belajar Mengajar $\left(\mathrm{X}_{1}\right)$ sebesar 0.736 menunjukkan apabila terjadi peningkatan Proses Belajar Mengajar $\left(\mathrm{X}_{1}\right)$ maka akan mengakibatkan penurunan variabel Prestasi Belajar(Y) sebesar 0.736 dengan asumsi variabel bebas lainnya konstan atau tidak berubah. Hal ini mengindikasikan Proses Belajar Mengajarberpengaruh terhadap Prestasi Belajar. Hal ini berarti semakin tinggi Proses Belajar Mengajarmaka cenderung dapat meningkatkan Prestasi Belajar.

c. Koefisien regresi variabel Lingkungan Belajar $\left(\mathrm{X}_{2}\right)$ sebesar 0,808 menunjukkan apabila terjadi peningkatan Lingkungan Belajar $\left(\mathrm{X}_{2}\right)$ maka akan mengakibatkan penurunan variabel Prestasi Belajar(Y) sebesar 0,808 dengan asumsi variabel bebas lainnya konstan atau tidak berubah. Hal ini mengindikasikan bahwa Lingkungan Belajarberpengaruh terhadap Prestasi Belajar. Hal ini berarti semakin tinggi Lingkungan Belajarmaka cenderung dapat meningkatkan Prestasi Belajar.

\subsection{Koefisien Korelasi $(R)$}

Koefisien korelasi digunakan untuk mengukur besarnya hubungan linier antara variabel bebas Proses Belajar Mengajar(X1), Lingkungan Belajar(X2), terhadap variabel terikat (Prestasi Belajar). Hasil perhitungan koefesien korelasi (R) dapat dilihat pata tabel 4.16.Berdasarkan tabel 4.13 menunjukkan bahwa koefisien korelasi (R) pada penelitian ini sebesar 0,527. Nilai korelasi ini menunjukkan tentang hubungan antara variabel Proses Belajar Mengajar (X1), Lingkungan Belajar di kelas(X2), terhadap variabel Prestasi Belajar(Y) sebesar 52.7. Untuk menginterpretasikan hasil korelasinya dapat dilihat tabel 4.5. di bawah ini :

Tabel. 4.5. Intrepetasi Korelasi.

\begin{tabular}{|c|c|}
\hline Interval koefesien & Tingkat Hubungan \\
\hline $0,00-0,199$ & Sangat rendah \\
\hline $0,20-0,399$ & Rendah \\
\hline $0,40-0,599$ & Sedang \\
\hline $0,60-0,799$ & Kuat \\
\hline $0,80-1,00$ & Sangat kuat \\
\hline
\end{tabular}

Jika dilihat pada tabel 4.5 nilai koefesien korelasi 0,527 berada pada kategori 0,40 - 0,599. Hal ini menunjukkan bahwa variabel bebas dan variabel terikat mempunyai hubungan sedang. Kesimpulannya bahwa hubungan antara variabel bebas dan variabel terikat bersifat positif. Sehingga saat variabel bebas Proses Belajar Mengajar(X1), Lingkungan Belajar(X2), meningkat maka variabel terikatnya (Prestasi Belajar) akan mengalami peningkatan.

\subsection{Pengujian Hipotesis}

H1 : diduga bahwa indikator komunikasi yang efektif terdiri dari indikator Proses Belajar Mengajar (X1), Lingkungan Belajar (X2), secara silmultan dan parsial terhadap Prestasi Belajar .

\subsection{Uji Parsial (Uji t)}

Uji parsial (uji t) digunakan untuk mengetahui apakah masing-masing variabel bebas secara parsial mempunyai pengaruh yang signifikan terhadap variabel terikatnya.Cara pengambilan keputusan dengan membandingkan nilai signifikansi t dengan nilai alpha $(\alpha)$.Apabila nilai signifikansi $\mathrm{t}<$ alpha $(\alpha)$ maka $\mathrm{H}_{0}$ ditolak dan $\mathrm{H}_{\mathrm{a}}$ diterima artinya hasilnya signifikan.Sedangkan apabila signifikansi t >alpha $(\alpha)$ maka $\mathrm{H}_{0}$ diterima dan Ha ditolakartinya hasilnya tidak signifikan.Hasil uji t dapat di lihat pada tabel 4.6.berikut ini: 
4.6. Hasil uji parsial

\begin{tabular}{|c|c|c|c|c|c|}
\hline \multicolumn{6}{|c|}{ Coefficients $^{\mathrm{a}}$} \\
\hline \multirow[b]{2}{*}{ Model } & \multicolumn{2}{|c|}{$\begin{array}{c}\text { Unstandardized } \\
\text { Coefficients }\end{array}$} & \multirow{2}{*}{$\begin{array}{c}\begin{array}{c}\text { Standardized } \\
\text { Coefficients }\end{array} \\
\text { Beta }\end{array}$} & \multirow[t]{2}{*}{$\mathrm{t}$} & \multirow[t]{2}{*}{ Sig. } \\
\hline & $\mathrm{B}$ & Std. Error & & & \\
\hline \multirow{3}{*}{$\begin{array}{l}1 \\
\text { (Const } \\
\text { ant) } \\
\text { x1 } \\
\text { x2 }\end{array}$} & -15.613 & 8.450 & & -1.848 & .068 \\
\hline & .736 & .337 & .293 & 2.181 & .032 \\
\hline & .808 & .397 & .273 & 2.035 & .045 \\
\hline
\end{tabular}

a) Hasil uji t variabel Proses Belajar Mengajar (X1) terhadap variabel Prestasi Belajar(Y) menghasilkan $\mathrm{t}$ hitung sebesar $2.181>1,67$ (t tabel) dengan nilai signifikansi $\mathrm{t}$ sebesar 0,000 . Hasil pengujian tersebut menunjukkan bahwa Sig. $\mathrm{t}<$ alpha $(0,05)$ maka pengaruh variabel Proses Belajar Mengajar(X1) terhadap variabel Prestasi Belajar(Y) adalah signifikan. Hal ini berarti $\mathrm{H}_{0}$ ditolak $\mathrm{H}_{\mathrm{a}}$ diterima. Sehingga apabila Proses Belajar Mengajar meningkat maka Prestasi Belajarakan mengalami peningkatan.

b) Hasil uji t variabel Lingkungan Belajar (X2)terhadap variabel Prestasi Belajar(Y) menghasilkan t hitung sebesar 2.035>1,67 (t tabel) dengan nilai signifikansi t sebesar 0,000. Hasil pengujian tersebut menunjukkan bahwa Sig. $\mathrm{t}<$ alpha $(0,05)$ maka pengaruh variabel Lingkungan Belajar(X2)terhadap variabel Prestasi Belajar(Y) adalah signifikan. Hal ini berarti $\mathrm{H}_{0}$ ditolak $\mathrm{H}_{\mathrm{a}}$ diterima. Sehingga apabila Lingkungan Belajar(X2)meningkat maka Prestasi Belajarakan mengalami peningkatan.

1) Uji Simultan (Uji F)

Uji simultan (Uji F) dilakukan untuk mengetahui apakah variabel bebas secara simultan (bersama-sama) mempunyai pengaruh terhadap variabel terikat. Cara pengambilan keputusan dengan membandingkan signifikansi $\mathrm{F}$ dengan nilai alpha $(\alpha)$ yaitu 0,05 . Apabila signifikansi $\mathrm{F}<0,05$ maka $\mathrm{H}_{0}$ ditolak dan $\mathrm{H}_{\mathrm{a}}$ diterima. Artinya variabel bebas berpengaruh secara simultan terhadap variabel terikat. Sedangkan, Apabila signifikansi $\mathrm{F}>0,05$ maka $\mathrm{H}_{0}$ diterima dan $\mathrm{H}_{\mathrm{a}}$ ditolak. Berdasarkan tabel 4.18 F hitung sebesar 16.606>2,61

\section{SIMPULAN}

Dari hasil pengumpulan, pengolahan dan analisa data penelitian yang berjudul Pengaruh proses belajar dan lingkungan belajar di kelas terhadap prestasi belajar di peroleh bahwa berdasarkan pengujian secara simultan pengaruh dari kedua variabel bebas terhadap prestasi belajar mahasiswa. pengujian hipotesis model regresi menggunakan uji $\mathrm{F}$.

\section{Daftar Pustaka}

[1] Hamzah 2009, Teori Motivasi dan pengukurannya. (Jakarta: PT Bumi Aksara)

[2] Hamalik, Oemar, (2005), Kurikulum dan Pembelajaran. Jakarta: Bumi Aksara

[3] A.Suhaenah Suparno, (2001). Membangun Kompetensi Belajar. Direktorat Jendral Pendidikan tinggi departemen Pendidikan nasional.

[4] Sri wahyuni, Moh Djazari, (2013). Kajian Pendidikan akuntansi indonesia.

[5] Baharudin, (2007). Teori Belajar dan Pembelajaran Jogyakarta: Ar Ruzz Media

[6] Sugiyono (2014),Metode Penelitian pendidikan Pendekatan Kuantitatif, Bandung.

[7] Nurgiantoro,Burhan(2011) Metodologi penelitian Pendidikan, Yogjakarta 